\title{
ヤブランとジャノヒゲ（ユリ科ヤブラン亜科）の種子 発芽特性 \\ Experimental Studies on the Seed Germination Characteristics of Liriope platyphylla and Ophiopogon japonicus (Liliaceae-Ophiopogonoideae)
}

鈴木貢次郎 ${ }^{*}$ 近藤 三雄*

Kojiro SUZUKI Mitsuo KONDO

\begin{abstract}
摘要：ユリ科ヤブラン覀科のうちジャノヒゲ属ジャノヒゲとヤブラン属ヤブランの種子発芽特性につ いて諸実験を行った。ジャノヒゲの種子の発芽率は, 種皮の色の違いによって異なった。種子の発芽 力は乾燥貯蔵によって失われ，低温湿潤貯蔵によって維持された。ヤブランの種子は, 種皮を除いた 方が高い発芽率を示した。また，採取直後であると暗条件下よりも明条件下の方が若干高い発芽率を 示す傾向があった。乾燥貯蔵によって種子の発芽かが失われたが, 低温湿潤条件下に貯蔵した場合で も時間の経過とともに発芽率が低下する傾向を示した。発芽適温は, ジャノヒゲで $20 \sim 30^{\circ} \mathrm{C}$ の間， ヤブランで 15 25ㄷの間にあった。
\end{abstract}

はじめに

ユリ科植物の多くは，花卉園芸用や農業用 作物として栽培されているが，また造園・緑 化用としての利用頻度も多い。例えば, ヤブ ラン带科のヤブランやジャノヒゲ，シュロソ ウ亜科のホトトギス,ッルボラン亜科のギボ ウシやへメロカリス，ユリ带科のユリ，クサ スギカズラ亚科のオモト等やそれらの近縁種 が, 主に観賞用として樹冠・林冠下の日陰地, 水辺地, 海岸や道路斜面等, 多様な空間に導 入されている。中でむ, ヤブラン亜科のヤブ ランとジャノヒゲは, 広範かつ多量に利用さ れている。またジャノヒゲは, 8 ケ月近い長 期冠水にも耐えられるほどの耐水性を持って 打り ${ }^{1)}$, 各種水辺地への導入植栽用之して, 巾でもダム湖などで問題となっている冠水裸 地面の緑化用として，応用が望まれる。

このような形での利用の增大をはかるため には，当然効率的な增殖法の確立が必要であっ て, 早くから株分けによる增殖が行われてい たジャノヒゲ属のうち, 園芸種チャボリュウ ノヒゲの組織培養法による大量増殖の試み などはその一例である。しかし, 大半のユリ 科植物と同じく, ヤブランとジャノヒゲは, 従米ほとんど栄養繁殖のみに依存してきた。 栄養繁殖による增殖の他には, 実生による増 殖が経济的にも有効之考えられるが，この両 種の種子発芽特性に関する研究は少なく, ヤ ブラン亜科の種了発芽特性に関する知見とし ては, ヤブランとジャノヒゲ種子の乾燥で発 芽力を失う性質 温度や光, 眝蔵の条件 ${ }^{12}$, Liriope muscari 種子の発芽に抢よぼす種皮の影響や種皮に含 まれる発芽抑制物質の性質などを報告した 例 ${ }^{23.3}$ があるのみである。

本稿は,このような実情を踏まえて, 特に
ヤブラン要科のうち, ジャノヒゲ, 別名リュ ウノヒゲ (Ophiopogon japonicus) 上ヤブ ラン(Liriope platyphylla) の 2 種について, 種子の発芽特性を調べたものである。

ジャノヒゲには熟度にかかわらず種皮の色 の異なる二つの種了材料があり, ヤブランに は採取時の熟度の違いによって種皮の色が異 なったので，それぞれの色の違いによる発芽 状況を比較した。それに加え，前述のように Liriope muscariの種皮に種了の発芽を抑止 する性質のあることが知られているので3, 供試両種についても発芽に対する種皮の影響 を調查した。また両種の種子発芽摔を向上さ せる処理方法の一っとしてジベレリン $\left(\mathrm{G} \Lambda_{3}\right)$ 施用の効果を調べた。

更に,これらの実験の結果に基づいて, 䝪 蔵期間 (種了秢), 温度条件および光条件を 㥞々に組み合わせ，それぞれの条件下での発

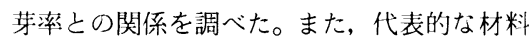
の発芽曲線を求めた。これは, 特に植生（播 種）工施用の際などに必要な情報となる発芽 速度㧍よび最終発芽倳に達する日数を確認す ることを研究目的のつとしたためである。

\section{1. 材料及び方法}

本研究の全ての発芽実験には, $0.1^{\circ} \mathrm{C}$ 刻み の温度設定が可能な恒温器（日本医科器械製 作所製 LH-200RDSMD 型）を用い，約 9000lux の蛍光灯で 1 日あたり 12 時間ずつ 照射して器内の温度と光の条件を調節した。 この照明条件下で，ガラスシャーレを用いて 明条件をそしてステンレスシャーレ(いず れ屯径 $9 \mathrm{~cm}$ ) を用いて暗条件を設定した。発 芽床にはろ紙を 2 枚敷き, 実験中は水道水を 常に浸るように潅水した。

ジャノヒゲには, 熟度に関係なく種皮が紺
色を呈するものと淡青色を呈するものの, 種 以下の分類階級で異にすると思われる二つの 種子材料があった。紺色系の種子は, 神奈川 県横浜市緑区内の山中に自生していた株から 1995 年 12 月 26 日に採取した。一方, 淡青色 系の種子は, 1993 年 12 月 28 日と 1995 年 12 月 27 日にそれぞれ横浜市緑区内の異なる民 家で栽培していた株から採取した。

なお，種子の色の異なるこれら二つの夕イ プは，採取した場所が異なることはもちろん， 淡青色の種子をつけている株は葉の長さが紺 色系の種子のものより多少短めであり，また 1 株から採れる種子の数にも, 淡青色系の 2 , 3 個に対し, 紺色系の 5 ～10 個という違い があった。これらのことから両群は同一種で あるが, 種以下の分類階級で異なるものと考 えられる。

ヤブランの供試種子は，1995 年11月9日 に東京都千代田区内の公園にお斿る栽培株之, 同年 12 月 24 日に横浜市緑区内の竹林の林床 に自生する株からそれぞれ採取した（以降， それぞれ東京産, 横浜産とよぶ)。東京産の ヤブランの種子には, 採取時点で同株からの 採取種子の中に, 熟度の異なる, 種皮が緑色 のものと黒色のものが含まれた。

発芽実験では各区之もシャーレ当たり 50 粒ずつの種子を置休し, 発芽能力をもつ種子 がすべて発芽を終えたと認められる時点まで (最大 98 日間), 週 1 回の頻度で発芽した種 子を数えて, 発芽摔と平均発芽日数を求めた。 平均発芽日数は， 7 日抢きに発芽した数上 7 日掞きの置床後日数 $(7,14,21, \cdots)$ との積の 総和を発芽総数で割った值で表した。

なお, 本実験中に記す種子齢とは, 採取直 後を 0 とし, 以降の貯蔵期間は, 月単位で表 した。 
種了齢を経た材料を扱う実験では，眝蔵条 件の違いによる発芽率の比較を行う实験で低 温乾燥条件下に眝蔵した種子を除き, 全種子 を低温湿潤（採取した種子をすぐにポリエチ レンビニール袋に密封し, $5{ }^{\circ} \mathrm{C}$ 冷蔵庫に入 れる）条件下に貯蔵した。

各実験の具体的な内容を, 以下の各項に示 す。

（1）種皮の色の異なる材料間の発芽率の比較 (i ) ジャ/ヒゲの種以下の分類階級で異に する材料間の比較

ジャノヒゲの種以下の分類階級で異にする, 種皮の色が紺色(1995 年に採取) と淡青色 （1993 年と 1995 年に採取）上の二つの材料間 で種子発芽率を比較した。実験は, $10^{\circ} \mathrm{C}$ か $30^{\circ} \mathrm{C}$ まで $5^{\circ} \mathrm{C}$ 問隔で温度条件を設定し，それ ぞれに明・暗条件を 3 反復ずつ設定した。ま た，いずれの種了材料についても，採取直後 （種了齢 0 ）に实験を行った。

（ii）ヤブランの熟度の異なる種子間の比較

東京㦃の緑色種子（若い）之黒色種了（成 熟）の間で発芽の違いを比較するため, 採取 直後之約 1 ヶ月経過後（種了齢 1 ）の 2 回, $20^{\circ} \mathrm{C}$, 明条件下で 3 反復の発芽試験を行った。 （2）種皮の除去㧍よび $\mathrm{GA}_{3}$ 処理が発芽にお よばす影響

種皮の有無が発芽に与える影響の違いを探 るために、ジャノヒゲとヤブラン兩種の・部 の種子の種皮を取り除いて発芽率の違いを調 べた。ジャノヒゲでは紺色系の種子と 1993 年に採取した淡青色系の種子を用いた。紺色 系の種子を扱った実験では $10^{\circ} \mathrm{C} ら 30^{\circ} \mathrm{C} ま$ での $5{ }^{\circ} \mathrm{C}$ 刻みの温度条件で, 明暗の光条件を 2 反復ずつ設定した。淡青色系の種子を扱っ た実験では $20^{\circ} \mathrm{C} の$ 温度条件で明暗の光条件 を 3 反復ずつ設定した。

また，ヤブランは十分に熟した黑色種皮の 東京泩, 横浜産の種子を用い, いずれも 20 ${ }^{\circ} \mathrm{C}$, 明条件下で 3 反復ずつ設定した。

さらに, G $\Lambda_{3}$ による発芽促進の効果を調 ベるために, ジャノヒゲとヤブランの両種子 を $\mathrm{GA}_{3}$ 水溶液に浸漬処理した。ジャノヒゲ は紺色系々淡青色系 (1993 年採取) の両方の 種子を実験に供した。このうち, 淡青色系の 種子は, 種皮を除いたものと除かないものを 扱った。いずれも, $20^{\circ} \mathrm{C}$, 明・暗条件下で $\mathrm{GA}_{3}$ 処理を行った。

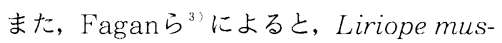
cariの種皮には発芽抑制物質が含まれている ことがわかっている。本実験で扱ったヤブラ ン(Liriope platyphylla) も同属であること から, 種皮によって発芽が抑制されることが あらかじめ予想されたので, ヤブランでは種 皮を除いて $20^{\circ} \mathrm{C}$, 明条件下で $\mathrm{GA}_{3}$ 处理を行っ た。供試種子は, 1995 年に東京と横浜で採取 した十分に熟している黑色種皮のものを用い
た。

$\mathrm{GA}_{3}$ 処理の実験では,ジャ/ヒゲとヤブ ランのいずれの場合も採取直後に実験を行い, すべて 3 反復設定した。G $\Lambda_{3}$ 水溶液は, $500 \mathrm{ml}$ の水道水に $\mathrm{GA}_{3}$ 粉末 $50 \mathrm{mg}$ を擋拌して 溶かし，種子を置床した際にろ紙にしみこま せた。実験開始後は, シャーレ内が乾かない ように水道水を同量ずつ潅水した。

（3）眝蔵条件による発芽率の比較

ジャノヒゲとヤブランの種子は乾燥によっ て生命力を失うといわ机ているのでフ，この ことを確認するために睦藏（特に湿度）条件 を変えた実験を行った。低温湿潤条件之低温 乾燥条件を設けて種子を定期間（ジャノヒ ゲ種了は 1 ヶ月間, ヤブラン種子は 4 ヶ月間) 眝蔵した後に発芽率を比較した。低温湿潤条 件の種了はポリエチレンビニール製の袋に密 封し (湿度約 80\%), 低温乾燥条件の種子は シリカゲルの入ったデシケーターに収めて (湿度約 30\%)，いずれも $5{ }^{\circ} \mathrm{C}$ 暗状態の冷蔵 庫に保存した。

ジャノヒゲの実験には淡青色系（1993 年 に採取）と紺色系の種子をまたたヤブランの 実験には横浜で採取した黒色種皮の十分に熟 した種子を，それぞれ用いた。

種子を眝蔵する際には, ジャノヒゲ，ヤブ ランとも種皮をつけたままにした。発芽試験 の際には, ジャノヒゲは種皮をつけたままで 行った。ヤブランはFagan ら の実験結果 から，前項之同じく種皮には発芽抑制物質が 含まれることを予测し，種皮を除いて発芽実 験を行った。各眝蔵条件から取り出した種了 をジャノヒゲは $25^{\circ} \mathrm{C}$ ，ヤブランは $20^{\circ} \mathrm{C}$ 明 条件下の実験に供した。実験区はいずれも 3 反復設定した。

（4）眝蔵期間（種子齢），発芽温度，光条件 と発芽率之の関係

上記までの各実験によって, 両種の種子の 種以下の分類階級での違いや熟度の違い， あ るいは種皮の有無が発芽に及ばす影響を明ら かにした。また種子の最適眝蔵条件も確認し た。

その後引き続いて種子発芽におよぼす温度 および明・暗の光条件の影響を明らかにする ための实験を行った。温度条件は, $10^{\circ} \mathrm{C} ら ら$ $30^{\circ} \mathrm{C}$ までの $5{ }^{\circ} \mathrm{C}$ 間隔の 5 段階に設定した。光 条件は, 明・暗の 2 通りとした。そして, 温 度条件と光条件の両者を組み合わせた 2 回反 復の実験区を設定した。結果は, 各種子齢ご とで温度と光の 2 因子の分散分析を行った。 実験期間は，採取直後から眝蔵期間 1 ヶ月刻 みでジャノヒゲは 5 ヶ月間, ヤブランの東京 産は 5 ヶ月間, 横浜産は8ヶ月間行った。

眝蔵条件は, 前項（3）の結果を参考にし て, ジャノヒゲ, ヤブランの両種子とも種皮 をつけたまま, 低温湿潤条件下（ポリエチレ
ンビニール製の袋に密封し $5{ }^{\circ} \mathrm{C} の$ 暗状態）の 冷蔵庫に保存した。

特にジャノヒゲの種子のうち, 紺色系のも のは, 1995 年 12 月に採取した直後の発芽試 験で低い発芽率を示した。これは, ヤブラン の種子が種皮によって発牙を抑制されるとい うFaganら の報告から, 同严科であるジャ ノヒゲも種皮による発芽抑制が原因の一つで あると考えた。そこで，本尖験では，この紺 色系の種子の種支を取り除いたものを実験に 供した。

ヤブランは, 前項 (3) と同じく, 十分に 熟した黒色種皮の種子を用い，種皮を取り除 いて実験に供した。

\section{2. 結 果}

本実験において発芽数を数えるための調查 期間を確認するため，また植生播種工への利 用のためには，種子を置休してからの発芽開 始日や終了日等の発芽状況 (発芽習性) を把 握する必要がある。そこで, 本实験の結果の 一部から発芽曲線（種子の置床後の日数之発 芽率の関係）を示した。

ジャノヒゲについては, 後述する, (1) 種 子の色の異なる材料間の発芽率の比較に関す る結果で, 1995 年に採取した淡青色系種了. が各温度において高い発芽率を示した。そこ で,その種子材料の明条件下に扔りる種皮付 きのままの発芽曲線を示した（図 1)。最も 発芽率の高かった $30^{\circ} \mathrm{C}$ 区で，置床後約 4 週 目に発芽を始め, 11 週日でほぼ最大值に達 した。一方, 辛うじて発牙することのできた $15^{\circ} \mathrm{C}$ 区で 10〜11 週にして漸く発芽を始め, 13 週日（91日目）には最大值に達した。 ヤブランについては, 種子材料の違いによ る発芽曲線の違いは小さかった。そこで, 本 結果では, (4)盯蔵期間 (種子齢), 温度, 光 条件と発芽率の関係に関する結果の横浜産種 子の明条件下, 採取直後の発芽曲線を示した (図 2)。

最も高い発芽率を示した $20^{\circ} \mathrm{C}$ 区で, 置床 後約 5 週日から発芽を始め, 概水 9 週目で発 芽洲が增加しなくなった。発芽率の最も低かっ た $15^{\circ} \mathrm{C}$ 区では明・暗条件ともに $5 ， 6$ 週日 から発芽が始まり, 13 週目（91日目）で最大 伯に達した。

（1）種子の色の異なる材料間の発芽率の比較 (i ) ジャノヒゲの種以下の分類階級で異に する材料間の比較

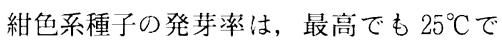
25\%程度だったのに対して, 淡青色系種了は, 1993 年採取のものが，20〜 $25^{\circ} \mathrm{C}$ の間で 40〜 $60 \%, 1995$ 年採取のものが, 20〜 $30^{\circ} \mathrm{C}$ の間で 100\%に達することがあった（网３）。また， 淡青色系の種子は紺色系に比べて平均発芽日 数が短かった（図 4 )。 
（ii）ヤブランの熟度の異なる種子間の比較

種皮が緑色の種子と黒色に熟した種子の間 では，種子齢に関わらず発芽率はほとんど差 がなかった（図 5 )。平均発芽日数は, 種子 齢 0 (採取直後) の実験で緑色種皮の種子が 黒色種皮の種子に比べて長くなったが, 種子 龄 1 の実験では差が小さかった（図6)。

（2）種皮の除去および $\mathrm{GA}_{3}$ 処理が発芽にお

\section{よばす影響}

\section{(i)ジャノヒゲ}

紺色系の種子は, $30^{\circ} \mathrm{C} の$ 明条件を除き，種 皮をつけたままの方が種皮を除いた場合より 屯高い発芽率を示した(図 7 )。一方, 平均発 芽日数は，種皮を除去した方がある場合より も短くなった（図 8 )。また, $20^{\circ} \mathrm{C}$ のでの 結果であるが，GAs浸漬処理を行った場合，
明・暗のいずれの光条件でも顕著に発芽率が 高まったり平均発芽日数が短くなる傾向は認 められなかった（図7，8）。

同様に，淡青色系のジャノヒゲ種子も，種 皮をつけたままの方が除いたものよりも発芽 率が高くなり(図 9 ), 平均発芽日数は種皮 を除いた方がつけたままのものよりも短くなっ た（図 10)。

また, $\mathrm{GA}_{3}$ 処理では, 平均発芽日数が短 くなった他は, 発芽率に・定方向の顕著な傾 向を示さなかった（図 9,10)。

(ii)ヤブラン

ヤブランは，種皮をつけたままの場合，明 暗の光条件や採取した場所に関わりなく著し く発芽に時間がかかり，発芽率も低かった。 一方，種皮を除去することによって著しく発
芽率が上昇した（危険率1\%以下で有意, 図 11)。種皮を除去した時の平均発芽日数は, 東京産で著しく短くなったが，横浜産はあま り変わらなかった（図 12）。

さらに種皮を取り除いて $\mathrm{GA}_{3}$ 浸漬処理を 加えた場合と種皮を除去したのみの場合とで は，発芽率抢よび平均発芽日数の差はほとん よ゙認められなかった（図 11,12）。

(3) 貯蔵条件による発芽率の比較

\section{(i)ジャノヒゲ}

淡青色系, 紺色系いずれの種子材料も，低 温湿潤条件下で約 1 ヶ月間保存した場合には 発芽が認められたが，乾燥条件下で保存する と，1ヶ月後には全く発芽か認められなくなっ た(図 13)。

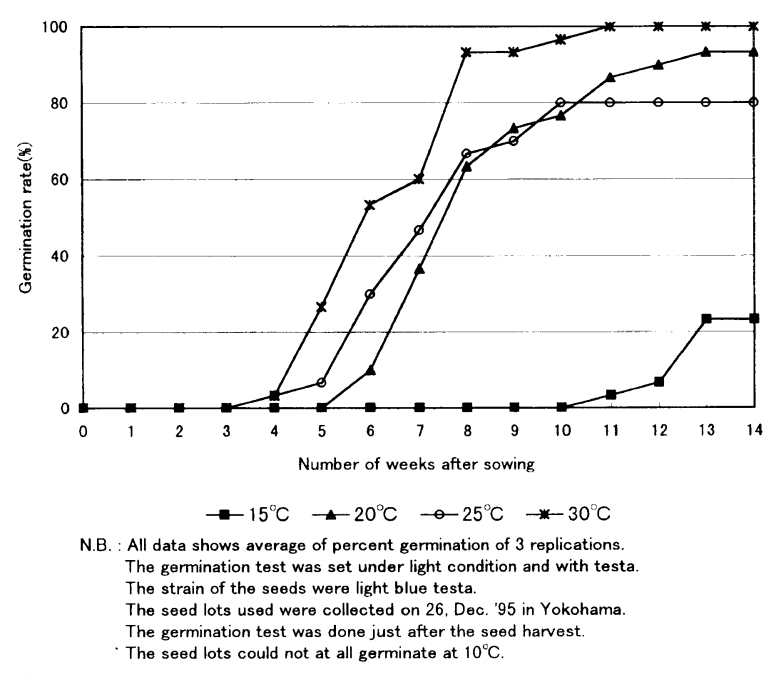

Fig.1 Relations between number of weeks after sowing and germination rate on the germination of Ophiopogon japonicus seeds.

図-1 ジャノヒゲの種子発芽における置床後の週数と発芽率の関係

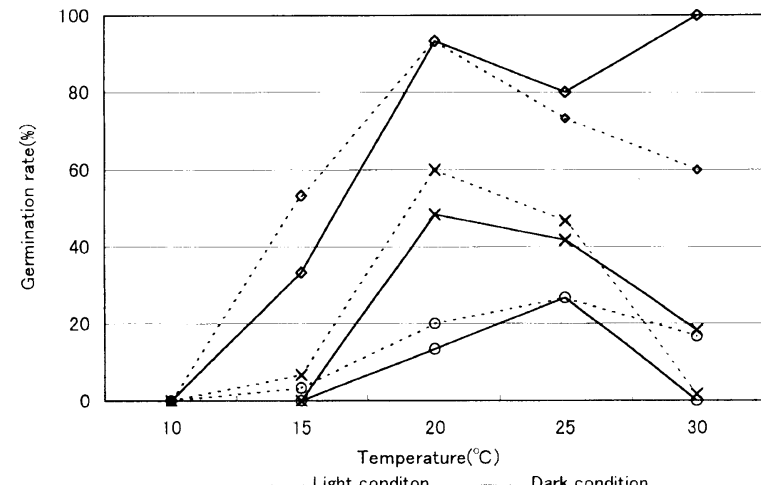

N.B. All data shows average of 3 replications of germination rate at 98 days after sowing.
The germination test was set with testa The germination test was set with testa

The germination test was done just after the seed havest

- Strain characterized by the seeds of dark blue testa (harvested in 26. Dec. '95) * Strain characterized by the seeds of light blue testa (harvested in 28. Dec. '93 - Strain characterized by the seeds of light blue testa (harvested in 27. Dec '95)

Fig.3 Germination rate of two strains of Ophiopogon japonicus characterized by the seed colors of seed testa under the condition of different temperatures and light conditions.

\section{図ー3種皮色を異にするジャノヒゲ 2 タイプの種子の異なる温度・ 光条件下の発芽率}

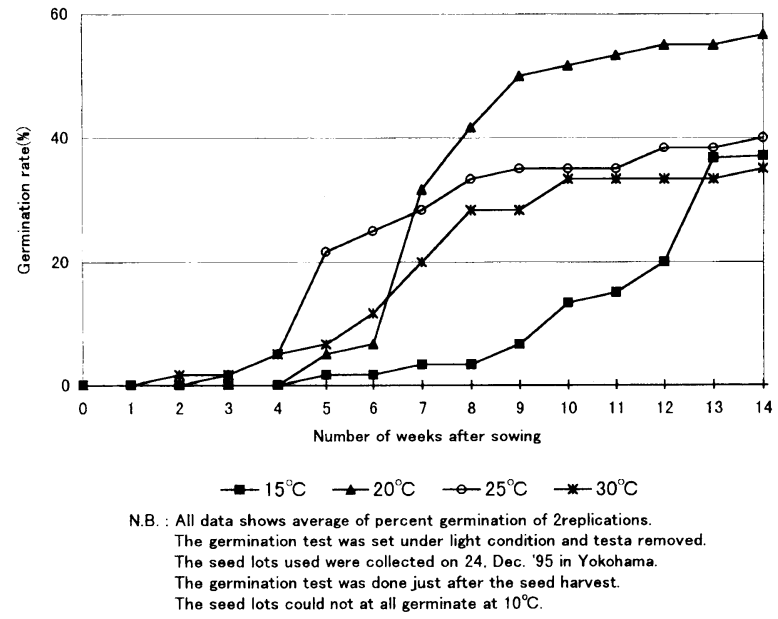

Fig.2 Relations between number of weeks after sowing and germination rate on the germination of Liriope platyphylla seeds.

\section{図ー 2 ヤブランの種子発芽における置床後の週数と発芽率の関係}

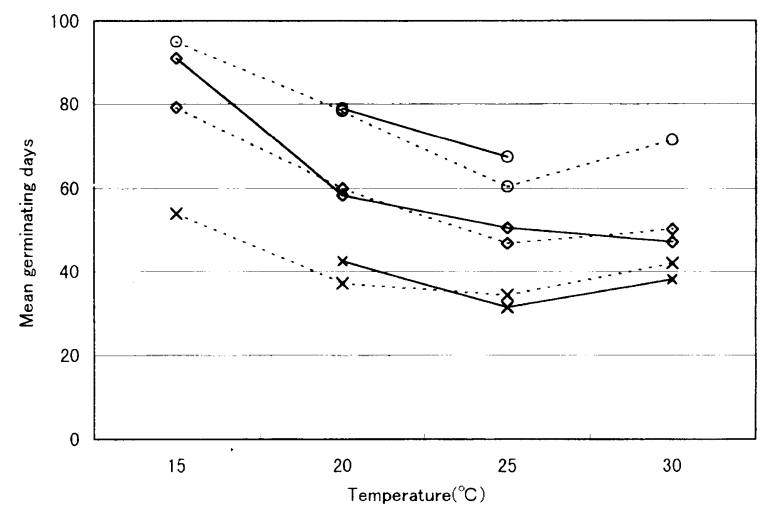

N.B. Symbols, materials and methods are the same as those of Fig. 3 . Mean germinating days is given by ' $\Sigma(f x) / \Sigma f^{\prime}$. [ $f$ : Each number of germination at intervals of 7 days., $\mathbf{x}$ : Number of days after sowing at intervals of 7 days $(7,14,21 \cdots)$.]

Fig.4 Mean germinating days of two strains of Ophiopogon japonicus characterized by the seed colors of seed testa under the condition of different temperatures and light conditions.

図ー4 ジャノヒゲ2タイプの種子の異なる温度・光条件下の平均発芽日数 


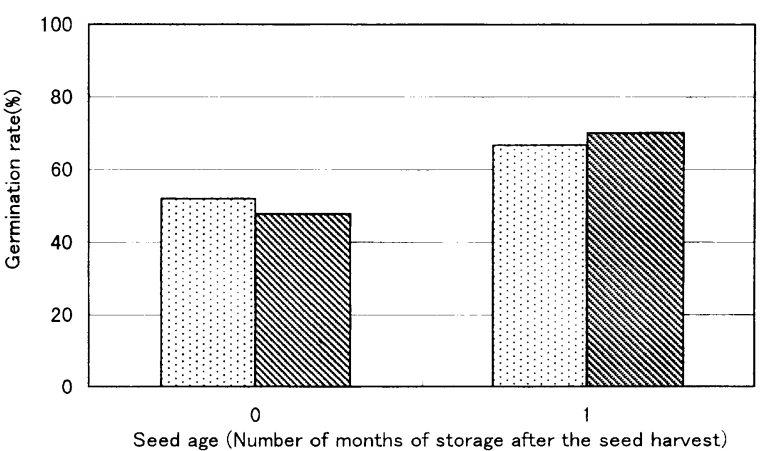

๑: testa green (young)

$\mathbb{\nabla}$ : testa black (mature)

N.B. : The seed lots used were corrected on 9 , Nov. ' 95 in Tokyo.

Germination test were done at $20^{\circ} \mathrm{C}$ and light conditions without test

All data shows average of 3 replications of germination rate at 98 days after sowing.

Fig.5 Germination rate of Liriope platyphylla seeds under two stages of maturity (green and black testa).

図－5 ヤブランの熟度(緑色と黒色種皮)の異なる種子の発芽率

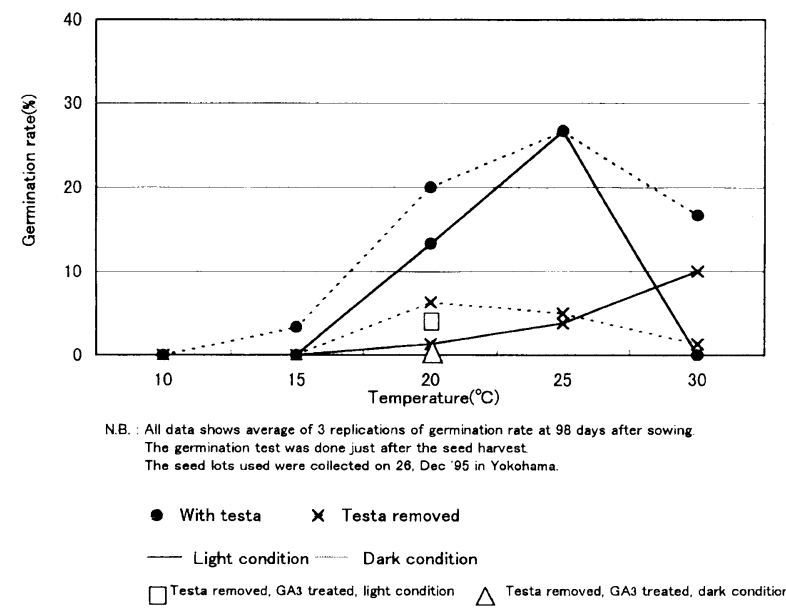

Fig.7 Effect of removal of testa and $\mathrm{GA}_{3}$ treatment on the germination rate of Ophiopogon japonicus seeds, by strain of seeds with dark blue testa.

図ー7 種皮の除去と $\mathrm{GA}_{3}$ 処理がジャノヒゲ種子(紺色系)の発芽率に およぼす影響

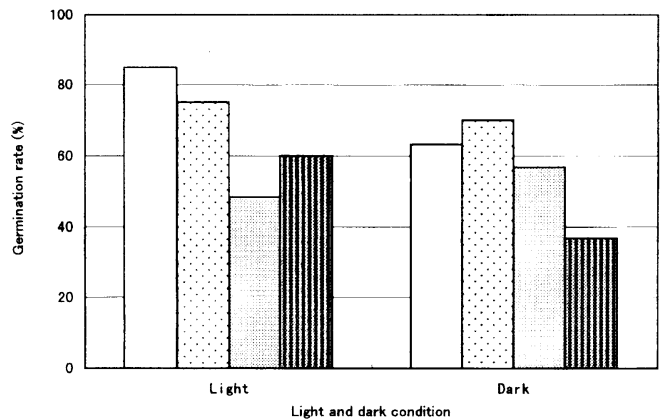

N.B. : All data shows averpar The seed lots used were collected on 28 , Dec. '93 in Yokohama.
The germination test was done just after the seed harvest under the condition of $20^{\circ} \mathrm{C}$.

口With testa

- Testa removed

WWith testa, GAs treated

由) Testa removed, GAs treated

Fig.9 Effect of removal of testa and $\mathrm{GA}_{3}$ treatment on the germination rate of Ophiopogon japonicus seeds, by strain of seeds with light blue testa.

図-9 種皮の除去よ $\mathrm{GA}_{3}$ 処理がジャノヒゲ種子(淡青色系)の発芽率
におよぼす影響

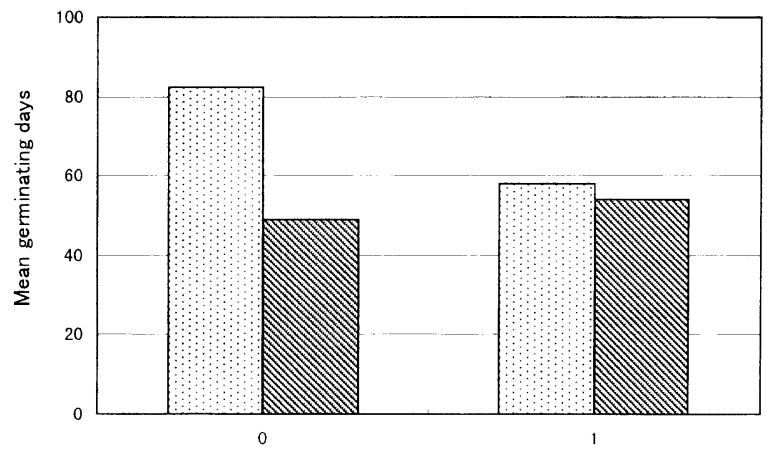

Seed age (Number of months of storage after the seed harvest)

N.B. : Symbols, materials and methods are the same as those of Fig.5. Mean germinating days is given by ' $\Sigma(\mathrm{f} x) / \Sigma f$ '.

[ $f$ : Each number of germination at intervals of 7 days., $x$ : Number of days after sowing at intervals of 7 days $(7,14,21 \cdots)$ ]

Fig.6 Mean germination days of Liriope platyphylla seeds under two stages of maturity (green and black testa).

図－6 ヤブランの熟度(緑色と黒色種皮)の異なる種子の平均発芽日数

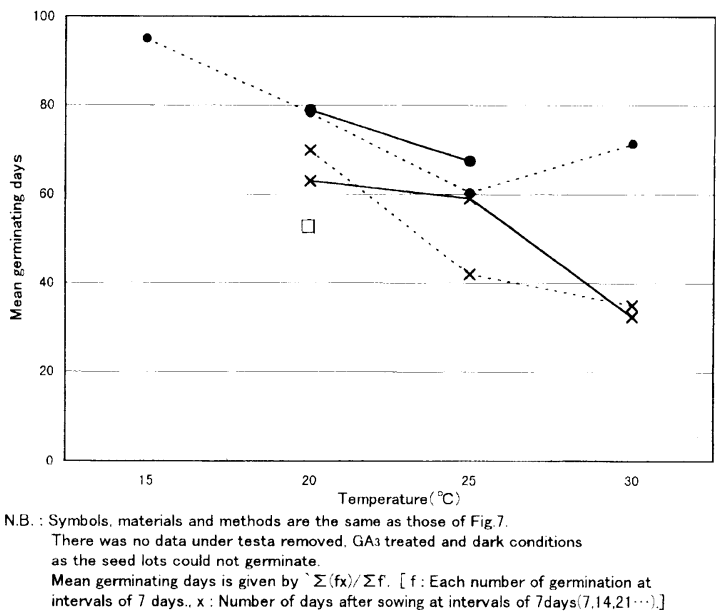

Fig. 8 Effect of removal of testa and $\mathrm{GA}_{3}$ treatment on the mean germinating days of Ophiopogon japonicus seeds, by strain of seeds with light blue testa.

図-8 種皮の除去と $\mathrm{GA}_{3}$ 処理がジャノヒゲ種子(紺色系)の平均発芽 日数におよぼす影響

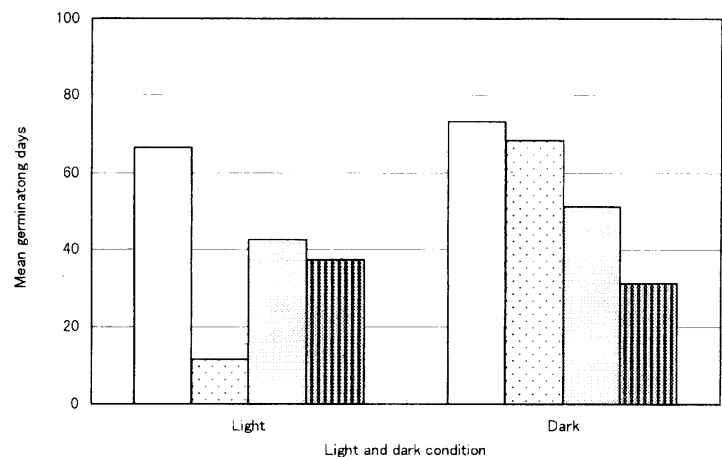

N.B. : Symbols, materials and methods are the same as those of Fig 9 Mean germinating days is given by $\bar{\Sigma}(\mathrm{f} \mathrm{x}) / \Sigma \mathrm{f}$. If ' Each number of germination at intervals

Fig.10 Effect of removal of testa and $\mathrm{GA}_{3}$ treatment on the mean germinating days of Ophiopogon japonicus seeds, by strain of seeds with light blue testa.

図一10 種皮の除去と $\mathrm{GA}_{3}$ 処理がジャノヒゲ種子(淡青色系)の平均発 芽日数におよぼす影響 


\section{(ii )ヤブラン}

低温湿潤条件下で保存すると 4 ケ月後でも 採取直後とほぼ同じ発芽率を示すが，乾燥条 件下で保存すると 1 ケ月後にはほとんよ゙発芽 しなくなり，4ヶ月で完全に発芽力を失って いた（図 14）。

なお，ジャノヒゲ，ヤブランの種子とも， 異なる眝蔵条件下によって発芽率の違いがはっ きりと現れたので, 平均発芽日数の結果につ いては図 13，14に補足的に図示した。種子 秢を経た時の平均発芽日数が, 採取直後の時 に比べて短くなったのは，ヤブランの種子を
低温湿潤条件下に睦蔵した時だけであった。 ジャノヒゲの種子齢を経た時の平均発芽日数 は, 低温湿潤条件下に眝蔵しても, 採取直後 と同程度か, かえって長くなった。

（4）貯蔵期間 (種了齢), 発芽温度, 光条件 上発芽渗之の関係

(i)ジャノヒゲ

本種は, 温度条件と種子齿によって発芽率 にばらつきがみられた（図 15）。まず温度条 件で比べると，いずれの明・暗条件下でも $10^{\circ} \mathrm{C}$ ではいずれの種子齢でも全く発芽が認め

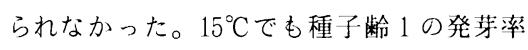

10\%を除いてほとんど発芽が認められなかっ た。 $20^{\circ} \mathrm{C}$ 以上の温度条件になると, 種子齢に よって多少のばらつきはあるが, 前二者に比 ベると種子齢 8 に至るまで 10２0\%台の発 芽率を維持していた。

これに対応するように，平均発芽日数も $15^{\circ} \mathrm{C}$ ではよ゙の種子歯も 70 ～100 と長くなるが, $20 \sim 30^{\circ} \mathrm{C}$ の実験では, $20^{\circ} \mathrm{C}$ の值が $25^{\circ} \mathrm{C}$ と 30 ${ }^{\circ} \mathrm{C}$ に比べて多少長めではあるがほぼ 20〜40 の範讲内にあった（戍 16）。

さらに，前項(1)にみたように（应 3 ), 1993，1995 両年に採取した淡青色系の種子は

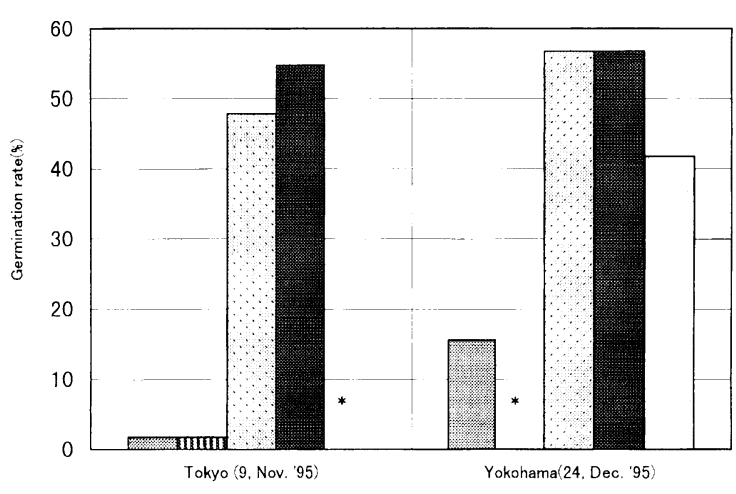

The seed lots used were corrected in

N.B. : All data shows average of 3 replications of germination rate at 98 days after sowin The germination test was set under $20^{\circ} \mathrm{C}$ and light conditions. A significant difference is found between the experiment with testa and that of testa removed by $F$-test at the level of $P<0.01$.

The germination tost was done just after the seed harvest

:The germination test was not set

With testa, light condition

With testa, dark condition

Testa removed, light condition

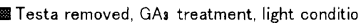

$\square$ Testa removed, dark condition

Fig.11 Effect of removal of testa and GAs treatment on the germination rate of Liriope platyphylla seeds.

図一11 種皮の除去よ $\mathrm{GA}_{3}$ 処理がヤブラン種子の発芽率におよぼす影響

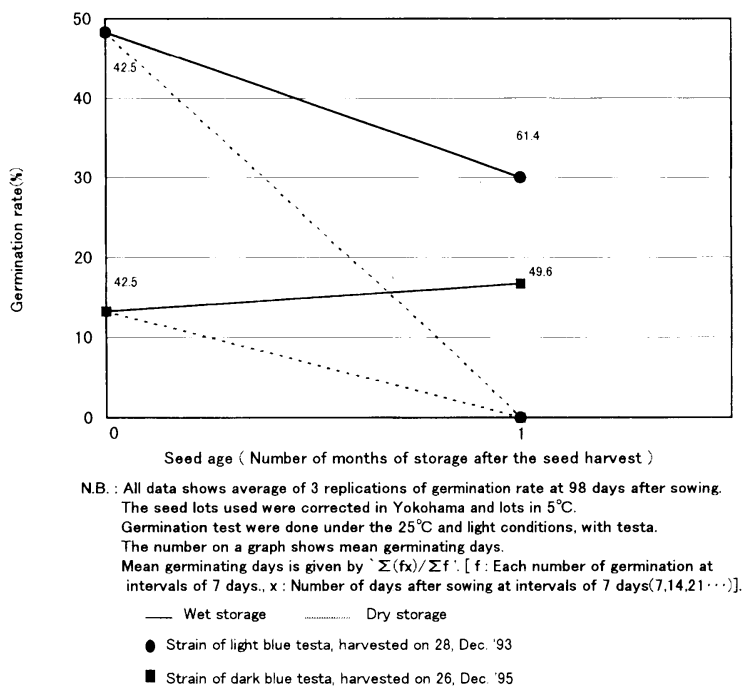

Fig.13 Germination rate of Ophiopogon japonicus seeds stored under different conditions.

図-13 貯蔵条件の異なるジャノヒゲ種子の発芽率

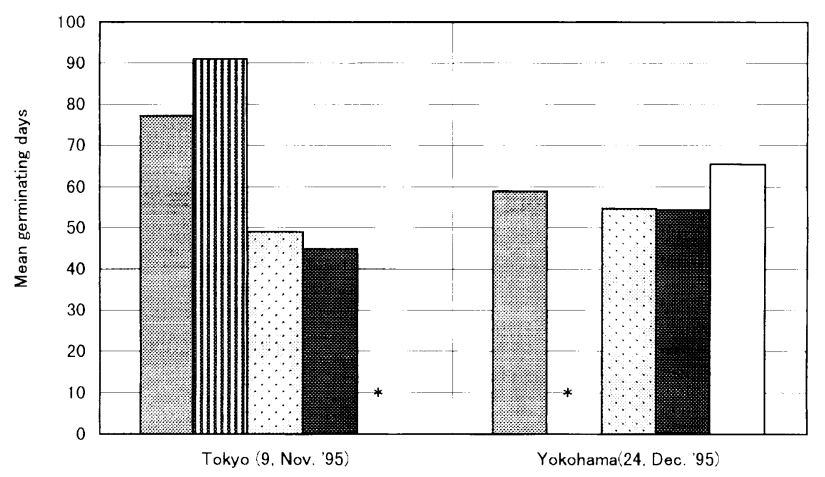

N.B. : Symbols, materials and methods are the same as those of Fig. 11 Mean germinating days is given by $\sum(\mathrm{fx}) / \Sigma \mathrm{f}$. [ $\mathrm{f}$ : Each number of germination at intervals of 7 days., $x$ : Number of days after sowing at intervals of 7 days $(7.14 .21 \cdots)]$

Fig.12 Effect of removal of testa and $\mathrm{GA}_{3}$ treatment on the mean germination days of Liriope platyphylla seeds.

図-12 種皮の除去と $\mathrm{GA}_{3}$ 処理がヤブラン種子の平均発芽日数におよ ぼす影響

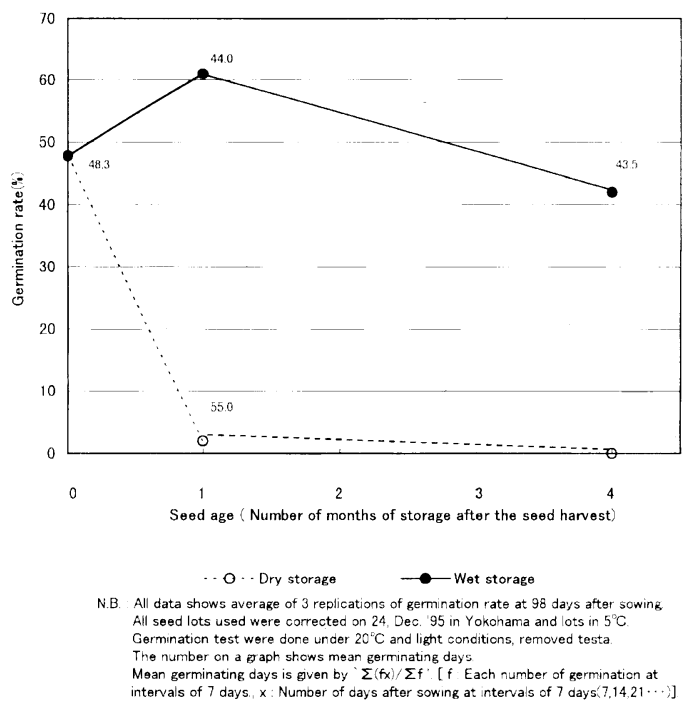

Fig.14 Germination rate of Liriope platyphylla seeds stored under different conditions.

図-14 貯蔵条件の異なるヤブラン種子の発芽率 
いずれも, 採取直後 1 回のみの実験結果であ

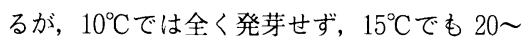
$30^{\circ} \mathrm{C}$ に比べて発芽率は劣っていた。また, 平

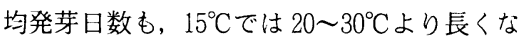
る傾向がみられた（図4)。つまり，ジャノ ヒゲ種子は, 種皮色の違いによって発芽率の 值は異なるが，いずれも20 $30^{\circ} \mathrm{C}$ の間に発 芽適温をもつと考えられた。

同梯に図 15 で，光条件と発芽との関係を みると, 種子齢 3 と 4 辺りを境に明・暗条件 での発芽率の值が入れ替わる傾问が認められ たが，その差は大きくても10\%程度であっ た。

なお, 前述のように, 採取直後に種皮をつ
けたまま行った実験の結果では（図 3 ), 1995 年採取の紺色系の種子にも, また, 1993, 1995 両年採取の淡青色系の種子にも，1995 年採取の淡青色系の種子の $30^{\circ} \mathrm{C}$ を除いて各 温度区で明・暗条件の発芽率の差は小さかっ た。いずれの種子, 温度条件でも明暗条件下 で比較した発芽率の差は，10\%水準でも有意 差か認められなかった。

(ii )ヤブラン

本種の場合, 東京, 横浜いずれの産地の種 子屯，種子歯 2 または 3 まではほぼ同じ水準 の発芽率を維持するが，それ以降は次第に低 下する傾向がみられた（図 17,18）。

発芽率と温度条件との関係をみると, 東京
産の種子は，いずれの明・暗条件下でも，種 子齢 2,3 までは $20^{\circ} \mathrm{C} て ゙$ 最も発芽率が高く, 若干順位は乱れるものの, ほぼ $15^{\circ} \mathrm{C}, 25^{\circ} \mathrm{C}$, $30^{\circ} \mathrm{C}$ の順に低くなった。種子齢 4, 5 では, $20^{\circ} \mathrm{C}$ に続き $25^{\circ} \mathrm{C}$ の発芽率が高くなるか，同 じになる傾向を示した（図 17）。なお，採取 直後の $20^{\circ} \mathrm{C}$ 以外の温度区では, 前述のよう に種皮をつけたまま実験を行ったためほとん ど発芽が認められず図示されていない。一方, 横浜産の種子は, 明暗それぞれの光条件下で,

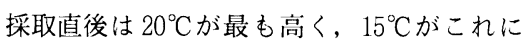
次ぎ，続いて $25^{\circ} \mathrm{C}, 30^{\circ} \mathrm{C}, 10^{\circ} \mathrm{C}$ 順に低くなっ た。東京産の種子齢 1,2 之横浜産の種子齢 0,1 とでは, $20^{\circ} \mathrm{C}$ 発芽摔が最も高いこと

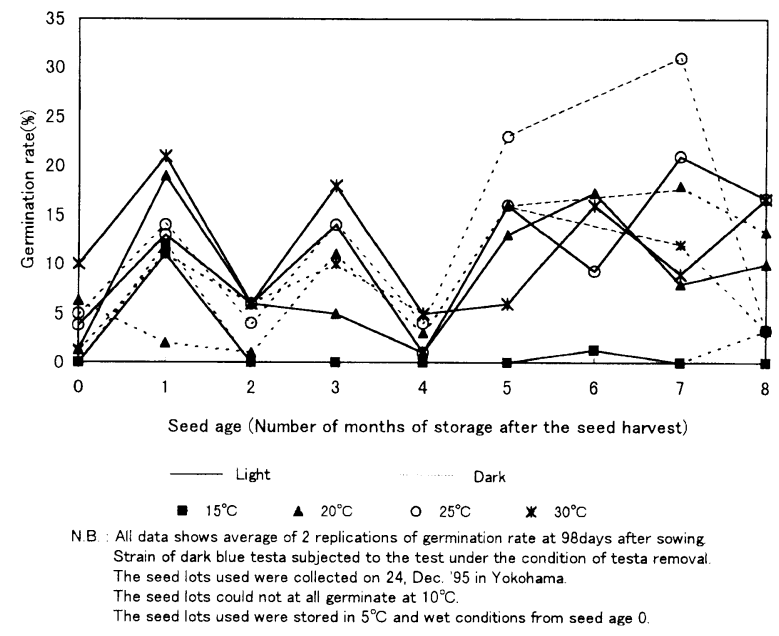

Fig. 15 Germination rate of Ophiopogon japonicus seeds stored during different periods (seed age), under different conditions of temperature and light conditions.

\section{図-15 貯蔵期間(種子齢)の異なるジャノヒゲ種子の各種温度・光条件 下における発芽率}

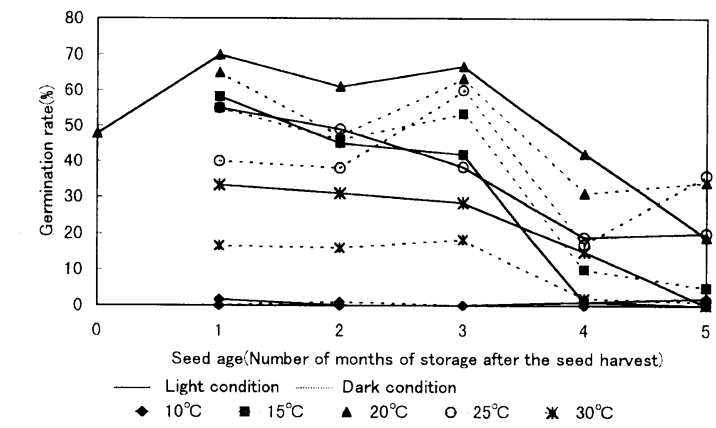

N.B. : All data shows average of 2 replications of germination rate at 98 days after sowing.

The seed lots used were collected on 9 . Nov. ' 95 in Tokyo. testa remova The seed lots used were stored in $5^{\circ} \mathrm{C}$ and wet conditions from seed age 0

\begin{tabular}{ll}
\multicolumn{2}{l}{ Seed age $(1$ and 2$)$} \\
\hline Source & Significance $(F: f 1, f 2)$ \\
\hline Temperature & $P<0.01(4,9)$ \\
Light & $P<0.1(1,9)$
\end{tabular}

Fig.17 Germination rate of Liriope platyphylla (harvested in Tokyo) seed stored during different periods (seed age), under different conditions of temperature and light conditions.

\footnotetext{
図-17 貯蔵期間（種子齢）の異なるヤブラン種子（東京産）の各種 温度・光条件下における発芽率
}

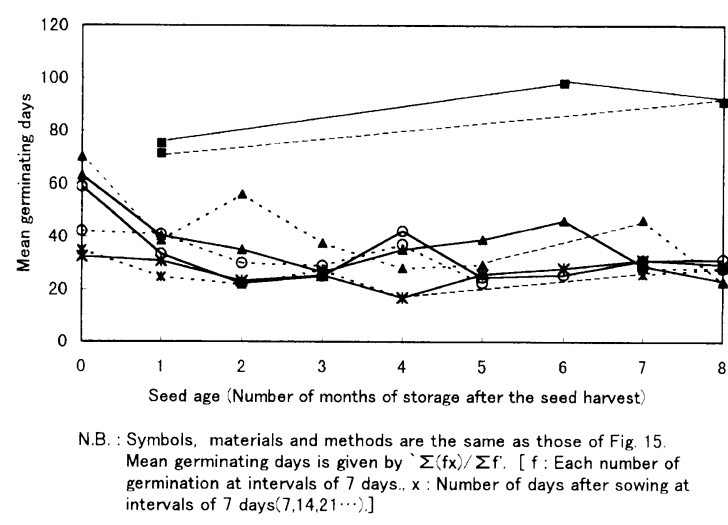

Fig.16 Mean germinating days of Ophiopogon japonicus seeds stored during different periods (seed age), under different conditions of temperature and light conditions.

図-16 貯蔵期間 (種子齢) の異なるジャノヒゲ種子の各種温度・光 条件下における平均発芽日数

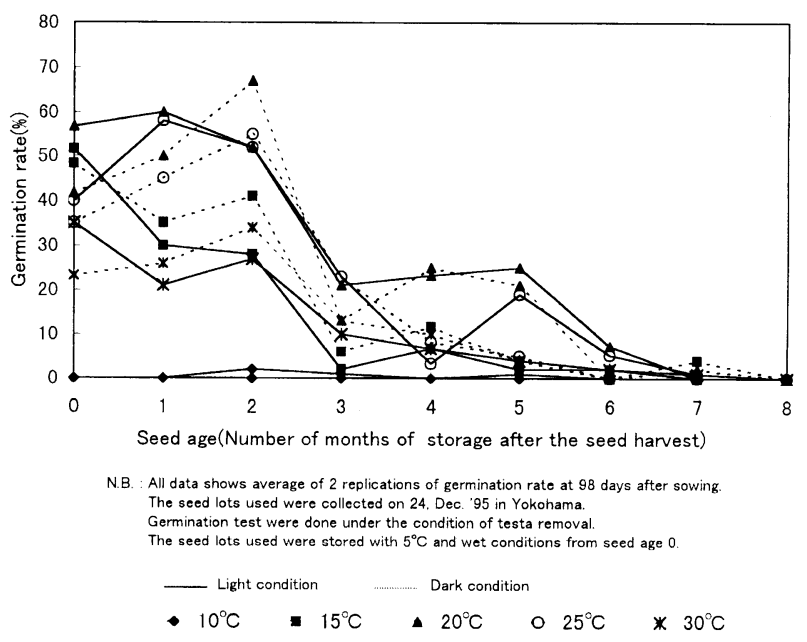

Fig.18 Germination rate of Liriope platyphylla (harvested in Yokohama) seed stored during different periods (seed age), under different conditions of temperature and light conditions.

図-18 貯蔵期間（種子䟧）の異なるヤブラン種子（横浜産）の各種 温度・光条件下における発芽率 


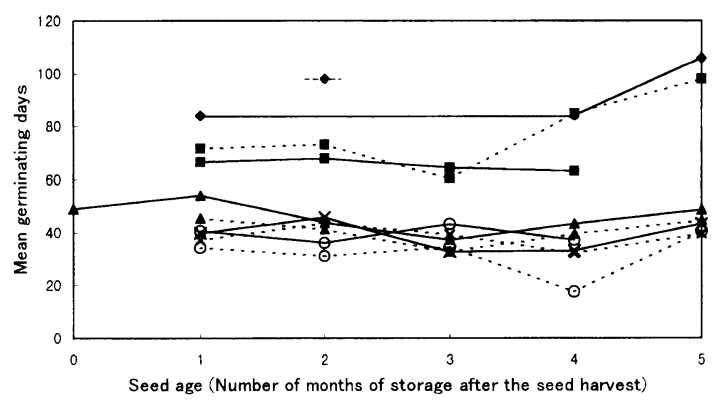

N.B. : Symbols, materials and methods are the same as those of Fig. 17 Mean germinating days is given by ' $\Sigma(\mathrm{fx}) / \Sigma \mathrm{f}$ '. [ $\mathrm{f}$ : Each number of germination at intervals of 7 days., $x$ : Number of days after sowing at intervals of 7 days $(7,14,21 \cdots)]$,

Fig.19 Mean germinating days of Liriope platyphylla (harvested in Tokyo) seed stored during different periods (seed age), under different conditions of temperature and light conditions.

\section{図-19 貯藏期間の異なるヤブラン種子（東京産）の各種温度・光 条件下における平均発芽日数}

が同じで $15^{\circ} \mathrm{C} に$ 代わって $25^{\circ} \mathrm{C}$ が次の位置を 占める（図 17,18）。つまり, 東京, 横浜産い ずれの種子も $15 \sim 25^{\circ} \mathrm{C}$ の間に比べて $10^{\circ} \mathrm{C}$ と $30^{\circ} \mathrm{C}$ で, 発芽率が低くなる傾向を有する。そ して, $20^{\circ} \mathrm{C}$ を最高に, 採取值後は $15^{\circ} \mathrm{C}$ 方が 高めであるが，採取後しばらくするとこれよ り $25^{\circ} \mathrm{C}$ の方が高くなった。平均発芽日数に は高温区 (20 30 $\mathrm{C}$ の間) の方が短くなる傾 向がみられた（図 19,20）。

次にヤブラン種子の発芽と光条件との関係 をみると, 東京産種子の場合, 種子齢 1,2 ま では $10^{\circ} \mathrm{C}$ 区および $15^{\circ} \mathrm{C}$ 区で，明・暗両条件 区の発芽率がほとんど同じであるが，20，25， $30^{\circ} \mathrm{C}$ の各区では明条件区の方が暗条件区より 高い発芽率を示した（危険率 10\%で有意）。 種子齢 3 以降は, $30^{\circ} \mathrm{C} \cdot$ 明条件区の発芽率が 暗条件区よりも高い值を示した他は，種子齢 及び温度区によって明・暗条件の発芽率の違 いが・定せず，明確な傾向を示さなかった (図 17)。横浜産種子の場合も, 採取直後に $\left(10^{\circ} \mathrm{C}\right.$ を除く) 各温度区で明条件区の発芽率 が少し高くなっているが，種子齢 1 以降にな ると順位と差が変動し，はっきりとした傾向 は見出されなかった（図 18）。

東京, 横浜で採取されたャブランの種子は, いずれも採取後しばらくは, 高温 $\left(20 \sim 30^{\circ} \mathrm{C}\right.$ の間）区で明条件下の発芽率が暗条件下より 高くなる傾向を示し，その後種子齢が高くな るに従って明条件下での発芽深が低下し，同 時に明・暗両条件の間の発芽率の差も見られ なくなった。

なお，ヤブラン種子の発芽と光条件との関 係に関する平均発芽日数の結果については, 一定の傾向か認められなかった（図 19,20）。

\section{3. 考 察}

部の実験の発芽率の結果から，発芽に必
要な情報となる発芽速度をもとめるためジャ ノヒゲ，ヤブラン両種とも代表的な材料を用 いて発芽曲線(種子の置床後の日数之発芽率 の関係)を描いた。その結果, 両種とも置床 後 4 週間目から発芽をはじめ, 11〜12 週間 目まで発芽を続けることがわかった。

そして，今回の実験によって同じヤブラン 亜科でも，ヤブランとジャノヒゲとでは，種 子の発芽特性, 特に発芽に対する種皮の除去 の影響，貯蔵条件，眝蔵期間（種子齢）なら びに温度および光の条件と発芽率との関係が 異なることがわかった。

まず、ジャノヒゲでは，種皮の色によって 紺色系と淡青色系に分けられたか，淡青色系 の種子は, 紺色系の種子より高い発芽率を示 した。淡青色系の種子は栽培株から, 紺色系 の種子は山中の自生株から採取したものであ る。また，淡青色系の中でも採取年によって 若干発芽摔が異なっていた。ここに見られた 発芽率の差は, 自生株と栽培品種との違い, あるいは年によって採取した場所が異なった ために生じた集団間の違い，色に現れない程 度の熟度の違い, 採取年の気候の違い等の理 由によるものと考えられる。

一方, ヤブランには採取時点で熟度の異な る緑色種皮の種子（若い）と黒色種皮の種子 (成熟) がみられた。両者の発芽率には差が 認められなかったが, 平均発芽日数は黒色種 子の方で短くなり,これには熟度が影響して いると考えられた。

更にジャノヒゲでは，種皮を保持する方が 除去した場合より高い発芽率を示した。これ は, ジャノヒゲの種子の種皮を除いた時に, 特にカビの発生が多かったことが, 原因の一 つと考えられた。抢そらくこのカビが胚乳に 何らかの障害を起こし, 発芽率の低下を招い たと考えられる。
また，ヤブランでは，種皮がついたままで あると明・暗のいずれの条件下でもほとんど 発芽せず，種皮を除去することによって著し く発芽率が上昇した。似たような現象として, Hancornia speciosa (Apocynaceae) の果

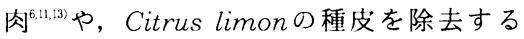
と ${ }^{5)}$ ，それぞれの発芽率が向上することが知 られている。また, Liriope muscariの種皮 にはフェノール系の発芽抑制物質が含まれて いるという3)。おそらく同じ属であるヤブラ ンの種皮にも類似の発芽抑制物質が含まれて いると思われる。

なお，東京産のヤブランは，種皮を除去す ると平均発芽日数が著しく短くなったが, 横 浜産についてはほとんど同じであった。これ は，横浜産の種子を採取したのが，東京産の 種子を採取したのに比べて約 2 ヶ遅かった ため熟度がすすんでいたという理由が考えら れる。

種子の発芽促進法として行った $\mathrm{GA}_{3}$ 処理 の効果は, ジャノヒゲ, ヤブランの両種とも 認められなかった。

種子の眝蔵方法に関しては, 早くに中島? が推測したように, ジャノヒゲ, ヤブランと も乾燥条件下に保存した場合には種子の発芽 力が失われたが, 低温湿潤保存によって発芽 力を維持することができた。特にジャノヒゲ 種子の眝蔵条件については, 乾燥によって急 激に発芽力を低下させる一方 $4{ }^{\circ} \mathrm{C}$ の湿潤条件 下で眝蔵すると少なくとも 3 ヶ月間は発芽力 を維持することを下村ら ${ }^{22}$ む明らかにしてい る。本実験の結果と眝蔵期間が異なるものの, 乾燥によって発芽力を失うことでは一致した。

なお, 同じ条件下で乾燥眝蔵しても, ジャ ノヒゲの種子は 1 ヶ月で全く発芽力を失った のに対し, ヤブランの種子は 1 ヶ月後でも僅 かながら発芽するものがあったという違いが 
みられた。

Faganら”は, Liriope muscari種子を 5 ${ }^{\circ} \mathrm{C}$, 乾燥条件下で 120 日間貯蔵した後に種々 の実験に供し, 高い発芽率を得た。しかし, 今回の研究でヤブラン (Liriope platyphylla）は, Fagan ら ${ }^{2)}$ が行ったの之同じ眝 蔵の温度と水分 (湿度) 条件で約 120 日後に 発芽力を失うという点でLiriope muscari種 子と異なる性質を示すことがわかった。今後, これらの種の違いや種子の貯蔵条件に対する 反応等を詳しく探る必要がある。

上記の基礎的な諸実験の結果を受けて, 採 取後直ちに種子をポリエチレンビニール袋に 密封し $5^{\circ} \mathrm{C}$ で湿潤保存して, 両種の種子の眝 蔵期間（種子齢）と発芽率との関係を調べた。 それによると, ジャノヒゲは, 若干のばらつ きを示してはいるが採取時から 8 ケ後まで 種子の発芽率をあまり低下させることはなかっ た。しかし，ヤブランでは 3,4 ケ後から 徐々に低下させる傾向がみられた。ヤブラン の種子が乾燥条件下で生命力を失うことは上 で述べた。これらのことを考え併せると，ヤ ブランの種子は, 湿潤, 乾燥のいずれの保存 条件でも生命力の短かいものであると考えら れる。

種子発芽に適する温度範囲は, ジャノヒゲ

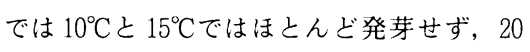
〜 30ㄷの間であった。ジャノヒゲ種子の発芽 温度については, 下村ら ${ }^{22}$ 屯同様の実験を行っ

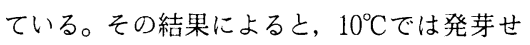

\section{引用文献}

1) 陳俊仁, 鈴木貢次郎, 高橋新平, 近藤三 雄 (1997): 水中に抢ける冠水時間之光 合成有効放射が植物の生育に及ぼす影響： 日本緑化工学会誌 22(4),228-235

2) Fagan,A.E., Dirr, M.A. \& Pokorny,F.A. (1981) : Effects of depulping, stratification, and growth regulators on seed germination of $\mathrm{Li}$ riope muscari. : HortSci.16(2),208-209

$3)$ Fagan,A.E., Dirr,M.A. \& Pokorny, F.A.(1982) : Investigation of anthocyanic pigments and substances inhibitory to Seed germination in the Fruit Pulp of Liriope muscari. : J. Amer. Soc. Hort. Sci.107(3), 468-476

4) Horikawa,Y. (1972) Atlas of the Japanese Flora : Gakken, pp.433

5) King,M.W. \& Roberts,E.H.(1980):
ず 20 〜 $25^{\circ} \mathrm{C}$ で最も発芽率が良好であったと 述へている。特に $30^{\circ} \mathrm{C}$ の発芽の低下につい てはカビの発生によるものと述べている。本 実験でも，特に紺色系種子のジャノヒゲの種 皮を除いた種子には, 高温 $\left(25 \sim 30^{\circ} \mathrm{C}\right)$ にな る程力ビの発生がみられた。力ビの発生に対 する処理方法は今後の課題ともなるが，いず

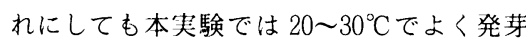
したことや，下村ら ${ }^{12}$ のカビの影響による 30 ${ }^{\circ} \mathrm{C}$ 発芽率の低下という結果から吟味すると, ジャノヒゲの種子は, 低温 $\left(10 \sim 15^{\circ} \mathrm{C}\right)$ より 屯高温 $\left(20 \sim 30^{\circ} \mathrm{C}\right)$ でよく発芽すると考えら れる。

また, ヤブランでは採取直後であると 15 $\sim 20^{\circ} \mathrm{C}$ の間, 数ヶ月を経ると $20 \sim 25^{\circ} \mathrm{C}$ の間之 いうように, $20^{\circ} \mathrm{C}$ を最適温度として $15 \sim 25^{\circ} \mathrm{C}$ の間に見出された。つまり，ジャノヒゲの方 がヤブランよりも発芽適温の範囲が高い方に あるといえる。ジャノヒゲとヤブランの分布 域は, 本州から沖縄となっておりりとんど違 いがないようである。しかし, ジャ/ヒゲと 同属のノシラン(Ophiopogon jaburan)が, 四国, 山陰, 九州以西の比較的気温の高い場 所に多く分布する゙ことから推測すると, ジャ ノヒゲの方がヤブランよりも発芽適温の範用 が高い方にあることを示唆できると思われる。 発芽と光条件との関係を探る実験では, ジャ ノヒゲの種子は, 紺色系の種子から種皮を除 いた実験区のみの結果であるが, 明・暗いず れの条件下でも発芽に違いを示さなかった。

The desiccation response of seeds of Citrus limon L., : Ann. Bot. 45, 489492

6) Ledoux, P.(1968) : Estudos sobre Hancornia speciosa Gom. (mangabeira) na regio equatorial amaznica. : Ciéncia \& Cultura20, 504-505

7) 中島庸三(1919）：乾燥二耐へザル種子： 植物雑誌 391, 169-172

8 ) 中村俊一郎(1954）：ゴボウ種子・の発芽に 関する研究（第1 報）：園芸学会雑誌 23(1),43-47

9 ) 中村俊一郎(1970)：タデ種子の発芽：山 口大学農学部学術報告 21,73-83

10）中村俊一郎(1972)：イチゴ種子の発芽: 園芸学会雑誌 41(4),367-375

11) Parente, T.V. and Machadao,J.W.B. (1986): Germinaçäo de sementes de mangaba (Hancornia speciosa)
また, 採取直後の実験で, 種皮が保持される 場合, 有意差は認められないが, 全ての温度 区で暗条件の方が明条件よりも発芽率が高かっ た。ゴボウ ${ }^{87}$, 夕デ97, イチコゴ"0)等では, 果 皮あるいは種皮を除去して胚部分のみを裸出 させると光感性（発芽におよぼす光の影響） を失うという例が知られているが, 同样にジャ ノヒゲの場合も種皮が光感性と何らかの関係 を有すると推測される。

なお, ジャノヒゲの淡青色系の種子が, 種 皮をつけたままの状態であると温度区によっ て明・暗両条件下の発芽率を逆転させて, 紺 色系の種了とは異なる結果を示したのは, 種 以下の分類階級を異にする材料間で光感性が 異なることを示唆するといえる。いずれにし ても, 紺色種皮の種子の光感性の存在ともど も, 本実験では推測の域を出ず, 今後さらに 究明する必要がある。

ヤブランでは, 採取時における明条件下の 発芽率が暗条件下より高くなる実験区が多かっ たが，時間を経るにつれて明条件下での発芽 率が低下し，次第にその傾向が少なくなった。

本研究は東京農業大学地域環境科学研究所 プロジェクト研究 (一般) 助成費による研究 成果の一部である。

本論文をまとめるにあたり, 東京農業大学 地域環境科学部 溜谷稔夫教授, 元東京農業 大学農学部 中村俊一郎教授にご指導を頂き ました。ここに厚く御礼申し上げます。

provenientes de frutos colhidos com diferentes graus de maturaçäo. : Revista Brasileira de Fruticultura8, 39-43

12）下村孝, 近藤哲也, 深井誠一 (1997)：リュ ウノヒゲ種子の発芽条件と眝蔵方法: 平 成 9 年度造園学会関西支部大会要旨集, 9-10

13) Tavares,S. (1960): Estudos sobre a germinçäo de sementes de mangaba (Hancornia speciosa Gom.) : Arquivos do Instituto de Pesquisas Agronô, icas, Recife5,193-222

14）養父志乃夫, 石川格, 大兽根兼一, 田中 繁男, 荻野徹, 河村止 (1991)：植物組織 培養法によるチャボリュウノヒゲの大量 增殖に関する研究 : 造園雑誌 54(5), 114119

(1997.11.8 受付, 1998.9.12 受理)

Summary : Several experiments on the seed germination of two liliaceous (Ophiopogonoideae) species, Ophiopogon japonicus, Liriope platyphylla represented us some new and interesting facts about its characteristics, as follows: (1) Between two types of Ophiopogon japonicus with seeds characterized by colors of testa, the type of seeds with light blue testa represented much higher germination rate than those with dark blue testa ; (2)The seeds of Liriope platyphylla changed the color of their testa from green to black according to maturity. But any difference of germination rate was not found between two groups of seed lots with each of these 
colors; (3)The seed lots of Liriope platyphylla heightened substantially their germination rate from nearly null up about $50 \%$ when their testa was removed ; (4)Steeping into gibberellic acid $\left(\mathrm{GA}_{3}\right)$ solution could not effectively break the dormancy of the seeds of both species; (5)The seeds with dark blue testa of Ophiopogon japonicus did not change their germinability under the influence of light condition and testa removed; (6)The seed lots of both species could not germinate at all when stored under dry condition for either period of one month or four months; (7) When stored under wet condition, the seed lots of Liriope platyphylla began to reduce the germinability in three or four months after the harvest, while those of Ophiopogon japonicus kept the initial germinability even in eight months; (8)The germination rate of Liriope platyphylla just after the harvest was higher under the light condition than under the dark ; (9)The optimum temperature for seed germination ranged from 20 to $30^{\circ} \mathrm{C}$ in Ophiopogon japonicus and from 15 to $30^{\circ} \mathrm{C}$ in Liriope platyphylla.

\section{日本造園学会関東支部緑化部会見学会 「千葉県立中央博物館生態園における生き物空間の管理」}

緑化部会は生き物空間の具体的管理技術というテーマで活動しています。今回は千葉県立中央博物館の 協力を得て、生態園の生き物空間としての管理について、生態園に関わっておられる学芸員の方の案内で 見学し、生き物空間の管理技術の確立という観点から討論します。

四場 所：千葉県立中央博物館（千葉市中央区青葉町 955-2 $80043-265-3111 ）$

口交 通: 電車・バスの場合 JR/京成 千葉駅 7 番バス乗り場からバスで中央博物館下車徒歩約 7 分 京成千原線千葉寺駅加徒歩約 15 分

自動車の場合＼cjkstart京葉道路松が丘インターチェンジから約 5 分（青葉の森公園北口駐車場を 利用 一日 500 円)

日日 時: 1999 年 2 月 27 日（土）13 16 時

集 合：千葉県立中央博物館本館 1 階講堂

口申 込：日本大学生物資源科学部造園学研究室に原則としてファックスで申し込んで下さい。 ซా 0466- 84-3628

参考書 : 中村俊彦・長谷川雅美「都市につくる自然一生態園の自然復元之管理運営」信山社

口その他：午前中に博物館の見学をされることをお勄めします（開館時間 午前 9 時〜午後 4 時 30 分）。 博物館内には軽食制茶があり、周辺にはファミリーレストランなどああります。 